\title{
СПІВПРАЦЯ УКРАЇНИ ТА АВСТРІЙСЬКОЇ РЕСПУБЛІКИ В КОНТЕКСТІ ГЛОБАЛІЗАЦІЇ ОСВІТИ, НАУКИ ТА КУЛЬТУРИ
}

\author{
Є. В. Сафар'янс
}

\begin{abstract}
Сафар’янс С. В. Співпраця України та Австрійської Республіки в контексті глобалізації освіти, науки та культури. У статті аналізується процес співробітництва України та Австрійської Республіки в освітній, науковій та культурній сферах на сучасному етапі. В контексті науково-освітньої та культурно-гуманітарної глобалізації розглянуто основні напрямки співпраці між обома державами. Досліджено процес українсько-австрійського співробітництва між науковими установами та навчальними закладами. Виявлено масштабний вплив освітніх програм та культурних заходів на рівень науково-освітньої кооперації України та Австрії.
\end{abstract}

Ключові слова: Україна; Австрія; співпраця; глобалізація; освіта; наука.

Сафарьянс E. В. Сотрудничество Украины и Австрийской Республики в контексте глобализации образования, науки и культуры. В статье анализируется процесс сотрудничества Украины и Австрийской Республики в образовательной, научной и культурной сфере на современном этапе развития. В контексте научно-образовательной и культурно-гуманитарной глобализации рассмотрены основные направления взаимодействия между обоими государствами. Исследован процесс украинско-австрийского сотрудничества между научными учреждениями и учебными заведениями. Выявлено масштабное влияние образовательных программ и культурных мероприятий на уровень научно-образовательной кооперации Украины и Австрии.

Ключевые слова: Украина; Австрия; сотрудничество; глобализация; образование; наука.

Safarians $Y$. V. Cooperation between Ukraine and the Republic of Austria in Context of Globalization of Education, Science and Culture. Author analyzes in the article the process of cooperation between Ukraine and the Austrian Republic in the educational, cultural and science spheres at the present stage. The main directions of cooperation between the two states are consideredin the context of educational, cultural and science globalization. Author researches the process of Ukrainian-Austrian cooperation between academic institutions and educational institutions. The scale impact of educational programs and cultural events on the level of scientific and educational cooperation between Ukraine and Austria has been revealed.

Keywords: Ukraine; Austria; cooperation; globalization; education; science.

В сучасному світі в науково-освітній та культурно-гуманітарній сферах відбуваються дуже стрімкі й кардинальні зміни. Інтернет тісно пов'язав найвіддаленіші куточки нашої планети та пришвидшив процес доступу до будь-якої інформації. «Всесвітня мережа» змінила потреби суспільства, інакшою стала сама освіта. Перед країнами Центрально-Східної Європи постали нові виклики, які змусили багатьох розпочати модернізацію та стати на шлях кооперації. Вже майже чверть століття в науково-освітній сфері плідно співпрацюють Україна та Австрія.

Метою даної статті є необхідність ознайомити читачів з новими тенденціями співробітництва між Україною та Австрійською Республікою в сфері освіти, науки та культури.

Одним із небагатьох австрійських істориків, хто приділив увагу в своїй статті українсько-австрійському науково-освітньому співробітництву, $є$ доцент Інституту сучасної історії та Інституту фахової дидактики університету Іннсбрука А. Брайт ${ }^{1}$. Про українськоавстрійське наукове співробітництво йдеться в статті В. Демченка ${ }^{2}$. Дослідження Р. Агстнера ${ }^{3}$ присвячені більш ніж двохсотлітній історії австрійсько-українських культурних зв’язків, а розвідка I. Славінскі ${ }^{4}$ - двостороннім культурним відносинам в XX ст.

В українській історіографії доволі мало уваги приділено співробітництву України та Австрійської Республіки на сучасному етапі в культурно-гуманітарній та науково-освітній сферах. Винятками є спільна стаття Н. Папенко та О. Лихачевої5, котрі пишуть про історичний вимір українсько-австрійських відносин, зокрема в сферах освітнього та культур-

(C) Сафар'янс, Є. В., 2018 
ного співробітництва, та стаття О. Песчаного ${ }^{6}$, котрий приділив увагу українсько-австрійській співпраці в 90-ті роки XX століття в сфері культури. Дослідження процесу австрійсько-українського науково-освітнього та культурного співробітництва на сучасному етапі частково присутнє в працях В. Васильчука ${ }^{7}$, Г. Дутчак ${ }^{8}$, В. Химинець

Отже, розвиток освіти в сучасному світі неможливий без науково-освітнього та культурно-гуманітарного співробітництва. Взаємодія між Австрією та Україною у цих сферах має великі можливості для розвитку та грунтується на положеннях «Меморандуму про співробітництво» між Міністерством культури і мистецтв, Міністерством освіти України та Федеральним міністерством освіти і культури Республіки Австрія, який був підписаний 27 вересня 1998 р. ${ }^{10} .17$ травня 2000 р. був доданий Протокол про внесення доповнень до згаданого Меморандуму щодо наукового співробітництва. Від 6 червня 2003 р. діє й нова Угода про науково-технічне співробітництво між Кабінетом Міністрів України та Урядом Республіки Австрія ${ }^{11}$. Пізніше - 21 травня 2004 р. - між обома країнами був підписаний новий Меморандум ${ }^{12}$, що продовжив дію попереднього меморандуму на п'ять років. Проте й на даний час він вважається чинним, оскільки чергова угода між державами так і не була укладена. В 2017 р. Кабінет Міністрів України та Уряд Австрії планували підписати угоду про співробітництво в освітній та культурній сфері ${ }^{13}$, але прийняття цієї Угоди неодноразово відтерміновували, а тому існує висока вірогідність того, що усі переговори будуть подовжені й наступного року. Велика увага була приділена співробітництву України та Австрійської Республіки в напрямку налагодження не тільки двосторонніх стосунків, але й в питаннях економічної, політичної та культурної взаємодії з Свропейським Союзом ${ }^{14}$.

Стаття 1 Меморандуму про співробітництво від 21 травня 2004 р. включає в себе положення про співпрацю в сфері культури, але особливої уваги заслуговує Стаття 2, яка стосується взаємовідносин в освітньому просторі за такими напрямками: «Обмін інформацією та досвідом 3 питань шкільного права, навчальних планів та розробки навчальних матеріалів, надання підтримки при проведенні структурних реформ у сфері шкільної освіти, надання допомоги в налагодженні міжшкільних контактів, співробітництво експертів у рамках розвитку шкіл та сфері управління школою, співробітництво при створенні білінгвістичних шкіл, проведення заходів з навчання і підвищення кваліфікації, передусім для вчителів, співробітництво у сфері професійно-технічної освіти та професійного навчання, обмін досвідом з питань освіти для дорослих, співробітництво у вивченні національних мов і країнознавства обох Сторін, обмін досвідом та співробітництво у сфері літератури, у видавничій та бібліотечній справах» ${ }^{15}$.

Процес співпраці в науково-світній та культурній сферах між Австрійською Республікою та Україною з самого початку 90 -х років XX ст. розвивався в напрямку, який дуже точно охарактеризувала в своїй статті дослідниця Ілона Славінскі: «Культурні зв’язки, які з Галичиною та Буковиною до кінця Габсбургської монархії були особливо близькими (...), відроджувались після розпаду Радянського Союзу у багатьох відношеннях» ${ }^{16}$.

3 самого початку австрійці створили в Україні організації, які полегшили процес співробітництва. В 1994 р. при посольстві Республіки Австрія в Україні було створено відділ культури, який з 1 квітня 2002 року було перетворено на Культурний форум в рамках реорганізації австрійської культурної зовнішньої політики ${ }^{17}$.

31998 р. функціонує «Австрійсько-Українське бюро співробітництва 3 науки, освіти та культури». 1 січня 2011 року бюро об'єдналося з філією Австрійської служби обмінів (OEAD) у Львові ${ }^{18}$.

У освітній і науковій сфері наслідком глобалізаційних процесів $\epsilon$ все більш активна співпраця між провідними науковими установами й вищими навчальними закладами України та Австрії.

Національна академія наук України та Австрійська академія наук плідно розвивають співробітництво в рамках 23-х спільних проектів 3 таких наук: математика, інформатика, астрономія, фізика, економіка, а такожу напрямі дослідження енергетики та матеріалознавства ${ }^{19}$. Ще у вересні 1992 року було створено Українсько-австрійський науковий центр Національної академії наук України ${ }^{20}$.

32007 р. успішно налагоджують зв'язки представники Дипломатичної академії при МЗС України та Віденської Дипломатичної академії; між цими установами було підписано 
Меморандум про співробітництво. Інші українські виші також налагоджують контакти 3 австрійськими навчальними закладами. 3 інститутами славістики та германістики Віденського університету співпрацює Інститут філології Київського національного університету імені Тараса Шевченка. 3 Віденським ветеринарним інститутом - Львівська ветеринарна академія, а Львівський національний університет імені Івана Франка взаємодіє та реалізовує спільні проекти з Університетом міста Зальцбург. Вдалим можна вважати співробітництво Національного університету «Львівська політехніка» 3 Технічним університетом міста Грац та Віденським технічним університетом; зокрема, в грудні 2015 р. Віденський та Львівський університети відзначили 20 -річчя своєї співпраці. Успішно виконується угода між Віденським економічним університетом та Київським національним економічним університетом, відповідно до якої передбачено навчання за спеціальною програмою українських студентів з кафедри німецької мови факультету міжнародних відносин. На юридичному факультеті Київського національного економічного університету імені Вадима Гетьмана вже більше 10 років діє спеціальна магістерська програма «Міжнародне економічне право». До створення цієї програми долучилися університети Відня (Австрія), Неаполя (Італія), Ньюкасла (Велика Британія) в рамках реалізації спеціального проекту «Теmpus-Tacis». Університет Альпен-Адріа міста Клагенфурт надав можливість студентам гуманітарних спеціальностей Чернівецького національного університету навчатись безкоштовно протягом семестру з допомогою спеціальної стипендіальної програми. Окрім Чернівецького, Університет Альпен-Адріа також співпрацює з Харківським національним технічним університетом та Житомирським державним університетом імені Івана Франка ${ }^{21}$.

Одним 3 найголовніших напрямків співробітництва між Австрією та Україною на сучасному етапі $є$ освітні програми та служба обміну. Більша частина заходів 3 академічної мобільності українців здійснюється у рамках програми Erasmus+, яка 32014 р. об'єднала у собі сім діючих європейських програм мобільності, зокрема й більш відому Erasmus Mundus. Для трьох магістрів Харківського національного технічного університету за спеціальністю «Інформатика» університет Альпен-Адріа 3 ініціативи професора Тільманна Ройтерана 2016-2017 навчального року надав щомісячні стипендії розміром 850 євро 22. Студенти, аспіранти та викладачі Львівського національного університету імені Івана Франка в рамках проекту Erasmus+ мають можливість навчатись упродовж першого семестру та проходити стажування у Віденському університеті ${ }^{23}$.

В рамках програми Erasmus Mundus EMERGEEU - Ukraine, Moldova, Belarus студенти, аспіранти та молоді науковці чотирьох українських університетів - Національного педагогічного університету імені М. П. Драгоманова, Національного університету «Києво-Могилянська академія», Національного технічного університету України «Київський політехнічний інститут» та Чернівецького національного університету імені Юрія Федьковича - мають можливість навчатися впродовж 1-2-го семестрів в Університеті імені Карла Франца австрійського міста Грац 3 щомісячною стипендією від 1000 до 2500 євро. Студенти та молоді науковці двох останніх українських вишів також мають можливість проходити навчання в Університеті Грацу в рамках програми Inter-academic network ERASMUS MUNDUS (IANUS), а з Національного університету «Києво-Могилянська академія», Чернівецького національного університету імені Юрія Федьковича та Прикарпатського національного університету імені Василя Стефаника беруть участь в програмі IANUS II. Програмою Erasmus Mundus Partnership for Belarus, Ukraine and Moldova (EMP-AIM) передбачена можливість академічної мобільності в Університеті імені Йоганнеса Кеплера австрійського міста Лінц на 1-2-й семестри з щомісячною стипендією від 1000 до 2500 євро для студентів, аспірантів та молодих науковців таких українських вищих навчальних закладів: Чернівецький національний університет імені Юрія Федьковича, Київський національний торговельно-економічний університет, Університет економіки та права “КРОК”, Київський національний університет імені Тараса Шевченка ${ }^{24}$.

Австрійська служба обмінів (OEAD), що була заснована ще 1961 р. спільним рішенням австрійських університетів, останнім часом пропонує все більший перелік послуг 3 міжнародного співробітництва в освітній сфері. Програма обмінів керує широким колом стипендіальних програм Федерального Міністерства освіти, науки і культури, Міністер- 
ства закордонних справ, Міністерства соціальної політики Австрії. Австрійська служба обмінів надає підтримку іноземним студентам та вченим, організовує стипендіальні програми, підготовчі курси та займається довідково-інформаційною діяльністю. Стипендіальні програми охоплюють усі напрями освітнього процесу: стипендії фонду стипендій Австрійської Республіки (Stipendium der Stipendienstiftung der Republik Ôsterreich) забезпечують підтримку студентів, випускників вишів та аспірантів, також є спеціальні докторські програми; стипендія Міжнародного інституту прикладного системного аналізу має програму для докторантів (IIASA-Funded Postdoctoral Program); стипендія для молодих науковців фізико-математичного профілю (ESI Junior Research Fellowships in Mathematics and Mathematical Physics); Стипедія для навчання в аспірантурі школи інформатики (Scholarships for the Vienna PhD School of Informatics); стипендії Фонду Пауля Урбана (Paul-Urban-Stipendienstiftung des Instituts für Theoretische Physik der Karl-Franzens Universität Graz); програма Лізи Майтнер для науковців (Lise Meitner Program for scientists from abroad); стипендія за міжнародною програмою магістерського рівня «Розробка інтегрованих систем і схем» (Scholarship for the international master degree program "Integrated Systems and Circuits Design"); перша демократична стипендія (1st Democratic Scholarship (Absolventae.V); стипендія фонду Монді для студентів (Mondi Austria Student Scholarship); всесвітня стипендія Ернста Mаха (Ernst Mach Stipendium - weltweit); стипендія Хердера в рамках Стипендіальної програми Альфреда Топфера (Herder Scholarship in the frame of the Alfred Toepfer Scholarship Programme) ${ }^{25}$.

Для підтримки загальноосвітніх проектів українське посольство в Австрії докладає максимальних зусиль.Торгівельна палата Австрії та австрійське Міністерство спорту профінансували у січні 2015 р. освітню подорож 200 українських дітей до східної Штирії, а влітку того ж року Посольство та уряди земель надали можливість відвідати Тіроль та Нижню Австрію одній сотні дітей з України ${ }^{26}$.

Посольство України також надає підтримку у Відні двом Українським Міжнародним школам: Українській суботній школі (УСШ) та Школі «Ерудит». Обидва цих заклади $є$ акредитованими Міністерством освіти України та підтримують зв'язки з Міжнародною українською школою у Києві. В історичній будівлі «Urania», де зараз діє УСШ, в 11-х класах школи щосуботи навчаються понад 120 дітей віком від 5 до 16 років. Учні мають можливість обирати навчання за українською шкільною програмою або ж вивчати лише українознавчі предмети (мову, історію, літературу та народну творчість). Заняття в школі проводяться в інтерактивній формі з метою збереження в учнів максимального зацікавленням процесом навчання. На території комплексу працює перша в Австрії музична школа $з$ українською мовою викладання ${ }^{27}$.

Трохи менша за масштабами, але доволі успішна Школа «Ерудит» у Відні працює за аналогічним принципом: окрім основної програми діють гуртки за вподобаннями, також на базі школи є можливість відвідати логопеда та отримати юридичну консультацію ${ }^{28}$.

На базі цих навчальних закладів здійснюється не лише викладання української мови та інших українознавчих предметів для жителів Австрії, але й організовано курси вивчення німецької мови для україномовних будь-якого віку: заняття проводяться у приміщенні Школи «Ерудит» та за підтримки Українського культурно-освітнього центру імені Івана Франка щосуботи у приміщенні Української суботньої школи у Відні ${ }^{29}$.

На базі центру німецької культури «Widerstrahl» у Києві працює екзаменаційний центр ÖSD Kiew, де $\epsilon$ можливість вивчити німецьку мову, підготуватися та скласти іспит на диплом ÖSD (Österreichisches Sprachdiplom Deutsch - «Австрійський мовний диплом»). Цей мовний диплом визнається в усьому світі ${ }^{30}$.

Модернізація освітнього процесу тісно пов'язана 3 полегшенням доступу до бібліотек та якісної інформації. Ще 1992 р. в Україні було відкрито 3 австрійські бібліотеки: одну було розміщено в Києві у просторі Національної бібліотеки України імені В. І. Вернадського, другу - у приміщенні Львівської наукової бібліотеки НАН України імені В. Стефаника, а третю - на території Чернівецького національного університету імені Юрія Федьковича. Також у 1996 році відкрито австрійську бібліотекув Харкові, а в 2009 році - в Дрогобичі. Усі відділення працюють досьогодні ${ }^{31}$.

За сприяння програми «Бібліоміст» Українська бібліотечна асоціація у партнерстві 3 Австрійською бібліотечною асоціацією організували освітню програму з питань практики 
адвокаційної діяльності. Захід проходив з 11 по 18 грудня 2010 р. у Відні. Учасниками були Президент і члени Президії УБА, директори бібліотек УБА, голови регіональних відділень УБА, заступник міністра культури України. Генеральний секретар Австрійської бібліотечної асоціації Геральд Ляйтнер презентував адвокаційну кампанію «Австрія читає». Для учасників програми були організовані візити до Австрійської національної бібліотеки, Публічної бібліотеки Відня, Бібліотеки Віденського університету, Бібліотеки музею «Альбертіна», Бібліотеки Віденського літературного дому та Офісу Австрійської бібліотечної асоціації. Учасники української делегації обмінювалися досвідом в процесі спілкування 3 австрійськими колегами. Для гостей проводили презентації, оглядові екскурсії ${ }^{32}$.

У листопаді 2016 року було розпочато новий проект Посольства України в Австрії зі Спілкою австрійських бібліотек. У рамках цього проекту, який повністю фінансувався австрійською стороною, провідні українські видавництва надали дитячі книги українською мовою головним бібліотекам федеральних земель Австрії ${ }^{33}$.

За підтримки Агентства США з міжнародного розвитку (USAID) було організовано програму (Participant Training Program) за напрямком «Розвиток інноваційних підходів в освіті». Захід відбувався у Австрії з 11 по 18 травня 2014 р. і був спрямований на розвиток потенціалу українських громадських інституцій міста Києва та Київської області. Проект передбачав обмін професійним досвідом, а також можливість ознайомитися з безпосередньою роботою американських та європейських колег. У рамках програми було приділено увагу специфіці сучасної особистісно-орієнтованої педагогіки, технології розвитку навчання та організації австрійської системи освіти. Учасників ознайомили з організацією процесу перевірки якості знань та підвищення кваліфікації вчителів в Австрії; також було презентовано основні інноваційні методи, які використовуються для роботи в освітній сфері Австрії. У межах програми учасники мали можливість ознайомитись з роботою органів державної влади Австрії (зокрема Міністерством освіти, мистецтва та культури), Федеральним інститутом освіти, наукових досліджень, інновацій та розвитку австрійської шкільної системи, Клагенфуртським університетом, освітніми центрами, педагогічними коледжами та школами 3 інноваційними підходами в освіті ${ }^{34}$.

До українсько-австрійської співпраці в освітній галузі долучаються й релігійні громади. У Львові в Патріаршому домі УГКЦ 4 травня 2017 р. відбулося вручення дипломів Австрійської освітньої програми для лікарняного душпастирства медичним капеланам УГКЦ. Навчання капеланів УГКЦ за медичною програмою тривало з жовтня 2014 р. до квітня 2017 р. і складалося $з$ шести блоків: три - в Україні, а три - в Австрії. Випускники цієї програми будуть впроваджувати сертифіковану програму для наступних капеланів в Україні. Освітню підтримку для програми надав Центр медичного капеланства у місті Зальцбург, який має багаторічну сертифіковану програму СРE - Clinical Pastoral Education (KSA - Klinische Seelsorge-Ausbildung) ${ }^{35}$.

В епоху глобалізації освіти важливими в процесі виховання населення стали просвітницькі заходи. В цьому напрямку українсько-австрійського співробітництва основна увага зосереджується на презентації української культурної спадщини і сучасного мистецтва.

29 серпня 1998 р. австрійці відкрили у Львові перший Культурно-інформаційний центр (КІЦ) на території України. Лише через вісім років - 17 жовтня 2006 р. - перший подібний український заклад був відкритий при Посольстві України в Австрії. 32006 р. Україна та Австрія починають реалізовувати програму Меморандуму. Українська громада в Австрії організовує різноманітні культурно-просвітницькі заходи, зокрема Шевченківське свято, Український бал, святкування Дня Соборності України, Український різдвяний вертеп, виступи українських мистецьких колективів ${ }^{36}$.

Українська громада Відня та Український культурно-освітній центр імені Івана Франка допомагаютьорганізовувати різноманітні заходи, зокрема екскурсії українською мовою до Віденської опери, святкування Дня святого Миколая та Водохреща, зустрічі з героями Антитерористичної операції (АТО) та визначними культурними діячами України. Спільними зусиллями українських громад в Австрії вдається організувати передачу дитячих малюнків та листів військовим у зону АТО, а також дитячих речей та грошей багатодітним сім'ям загиблих бійців ${ }^{37}$. Одними 3 перших спільних культурних заходів стали в 2006 р. Дні культури України в Австрії, а вже в 2008 р. були організовані Дні Відня у Києві, Чернівцях та Львові ${ }^{38}$. 
Посольство України у Відні підтримує організовані українською громадою культурні заходи. Кафедра міжкультурної комунікації та перекладу факультету іноземних мов Львівського національного університету імені Івана Франка в партнерстві з Віденським університетом та за участі OEAD презентували антологію німецькомовних творів Івана Франка «Vivere Memento», приурочену до ювілею великого українського письменника i поета. Збірку презентували 27 травня 2016 р. в Дзеркальній залі Львівського університету iii безпосередні упорядники: завідувач кафедри міжкультурної комунікації та перекладу Алла Паславська, заступник директора інституту славістики Віденського університету Алоїс Вольдан та лектор OEAD Тобіас Фогель ${ }^{39}$.

Ця збірка також була презентована у Віденському університеті та на з'їзді славістів Австрії в Зальцбурзі. На початку червня 2016 р. в рамках святкування ювілею Івана Франка пройшли Дні Львівщини у Відні. В перелік заходів було включено моновиставу Романа Горака - директора Львівського літературно-меморіального музею Івана Франка, мультимедійну презентацію Богдана Тихолоза та документально-літературну виставку ${ }^{40}$.

За підтримки посольства України в Австрії 2016 р. було організовано перегляди та обговорення українських документальних та художніх фільмів. У січні австрійській публіці показали фільми українського режисера Сергія Лозниці «Майдан» та «Подія», а вже в березні 2016 р. спільно з Посольством США було організовано демонстрацію фільму Євгена Афінєєвського «Зима у вогні». У квітні того ж року в австрійському місті Лінц у рамках щорічного фестивалю європейського кіно «Crossing Europe» було показано фільми «Пісня пісень» та «Українські шерифи». До 30-ї річниці аварії на Чорнобильській АЕС приурочили показ у Австрії фільму «Бабусі Чорнобиля», а у червні 2016 р. в Австрії було організовано ретро-показ культового фільму Олександра Довженка «Земля».

За підтримки Посольства України в Австрії з 13 квітня по 18 травня 2016 р. у Лінці експонувалася виставка відомого українського художника Дениса Савченка під назвою «Sehnsuchtsorte»" ${ }^{41}$. На відкриті експозиції виступила його дружина - відома співачка Інна Савченко, у травні 2016 р. за її участю пройшли два концерти «Ach! jenes Landder Wonne, das seh' ich oft im Traum», а у жовтні вона знову виступила в Лінці на фестивалі Bruckner Fest.

У Відні в 2016 р. за сприяння Посольства України відбулась низка заходів: виставка сучасного українського мистецтва (березень), концерт Луганського академічного симфонічного оркестру під керівництвом австрійського диригента Курта Шміда (квітень), а вже у жовтні оркестр виступив 3 програмою «Віденська осінь» у Сєвєродонецьку ${ }^{42}$, де 32014 р., тобто з моменту окупації окремих районів Донецької та Луганської областей (ОРДЛО) грає оркестр. У серпні 2016 р. було організовано виставку сучасної української іконографії, а в жовтні відкрито експозицію художника Івана Твердуна. Цього ж року в червні-липні в Карінтії діяла експозиція українських художників Олександра Літвінова та Наталії Вайнбергер. Австрійська публіка у листопаді 2016 р. змогла познайомитись 3 новинками української модної колекції відомого дизайнера Оксани Полонець. У грудні цього ж року було презентовано музику у виконанні Яромира Бабського і Дмитра Клименка та їхньогодиску «Класика з України», а також відбувся спільний концерт сучасних українських гуртів daKooka та дуету Zapaska ${ }^{43}$.

У травні-червні 2016 р. тривав найбільший фестиваль культури в Австрії-Вінер Фествохен. В його рамках відбулись 4 виступи 3 аншлагом жіночої групи «Dakh Daughters» ${ }^{44}$, яка виступає в стилі фрік-кабаре, аза мотивами роману Станіслава Лема в постановці Андрія Жолдака відбулася прем’єра вистави «Соляріс».

330 червня по 1 липня 2016 р. Посольство України в Австрії провело Дні української культури в Зальцбурзі. Особливо зацікавив публіку спів і музика Мар'яни Садовської під час презентації виданого німецькою мовою роману Наталки Сняданко «Пані Мюллер не налаштована платити більше» та сольний концерт співачки Лєни Бєлкіної. Відвідувачам під час фестивалю було показано експозицію 3 шедеврів Петриківського розпису ${ }^{45}$.

Окрім популяризації творів Наталки Сняданко, в Австрійській Республіці також відбувались читання творів українською та німецькою мовами інших відомих українських авторів: Софії Андрухович, у березні - Мар'яни Гапоненко, у травні - Богдана Коломійчука, в червні - Олега Шинкаренка, у липні - Сергія Жадана, а у вересні - Ірини Вікирчак. У жовтні 2016 р. українську письменницю та поетесу Мар'яну Гапоненко запросили на фестиваль «Австрія читає» як почесного гостя ${ }^{46}$. 
У травні 2016 р. вийшов випуск австрійського літературного журналу «Рodium», що був повністю присвячений Україні та українській літературі. Окрім упорядниці журналу Тані Малярчук над номером майже рік працювали перекладачі Марія Вайсенбьок і Гаральд Фляйшман та львівська дизайнерська студія «Аграфка» ${ }^{47}$. У жовтні відбулася презентація цього випуску.

327 жовтня 2016 р. по 12 лютого 2017 р. в Віденському Зимовому Палаці, колишній резиденції принца Євгена Савойського, тривала виставка скульптур львівського митця епохи бароко Йоганна Георга Пінзеля ${ }^{48}$.

Провівши аналіз наведеної інформації можна зробити такі висновки. 3 моменту набуття Україною незалежності процес співробітництва між державами розвивався доволі повільно. Українська сторона проявила слабкий інтерес до можливого поглиблення культурних зв'язків з Австрією, незначні контакти були налагоджені, в першу чергу, в науково-освітній сфері. Не було достатньої зацікавленості Україною і з австрійського боку, за винятком західноукраїнських земель - Галичини та Буковини, які в минулому входили до складу Австро-Угорської монархії. Проте під впливом подій Революції Гідності в Австрії почав зростати інтерес до української культури. В статті наведений доволі неповний перелік взаємних заходів, які відбувались в Австрії та Україні впродовж останніх трьох років. Він свідчить про відчутне поглиблення відносин між обома державами. Співробітництво між Україною та Австрійською Республікою в контексті глобалізації освіти, науки та культури впродовж останнього часу стало можливим саме завдяки зацікавленості обох сторін. Необхідним фактором для успішної співпраці $є$ наявність взаємного інтересу до національних культур з боку громадян обох країн, а також готовність урядів забезпечити підтримку такого інтересу. Це знайшло своє відображення в роботі багатьох неурядових організацій та реалізації громадських ініціатив. Важливим елементом співпраці в освітній галузі стало співробітництво між окремими навчальними закладами обох держав. Аналогічна ситуація й у науковій сфері, зокрема плідно розвивається співробітництво між академіями наук. В обох випадках ці тенденції варто вважати позитивними зрушеннями в справі успішної міждержавної взаємодії.

${ }^{1}$ Brait A. Wien-Moskau und Wien-Kiew. Der Zusammenbruch der UdSSR und die neue Unabhängigkeit der Ukraine aus der Wiener Perspektive // Австрія й Україна на історичних перехрестях: наук. зб./ упоряд.: І. В. Жалоба, О. Р. Купчик, Л. В. Шпаковськи. К.: Дипломат. акад. України при МЗС України, 2016. C. 39-74.

${ }^{2}$ Demchenko V. Zustand und Perspektiven der ukrainisch-österreichischen Wissenschaftsbeziehungen // Der Donauraum. 1997. 4 (37). S. $42-47$.

${ }^{3}$ Agstner R. Von Kaisern, Konsuln und Kaufleuten - Österreich und die Ukraine 1785-2010. Münster, 2011. S. 200.

${ }^{4}$ Slawinski I. Die Kulturbeziehungen zwischen Österreich und der Ukraine im 20. Jahrhundert /Viribusunitis. Österreich Wissenschaft und Kultur im Ausland. Impulse und Wechselwirkungen. Festschrift für Bernhard Stillfried aus Anlaß seines 70. Geburtstags, Bern/ Berlin/ Frankfurt am Main/ New York/ Paris/ Wien, 1996. S. 351-361.

${ }^{5}$ Папенко Н., Лихачева О. Австрійсько-українські відносини: історичний вимір // Вісник Київського національного університету імені Тараса Шевченка. К.: «Київський університет», 2013. С. 51-55.

${ }^{6}$ Песчаний $О$. O. Австро-українські стосунки 90-х років XX століття на сторінках «Вістей СУФА» та «Австрійсько-українського огляду» / Сумський історико-архівний журнал. 2010. № VIIIIX. C. 118-123.

${ }^{7}$ Васильчук В. Австрійці в українському історико-культурному процесі // Австрія й Україна на історичних перехрестях: наук. зб./ упоряд.: І. В. Жалоба, О. Р. Купчик, Л. В. Шпаковськи. К.: Дипломат. акад. України при МЗС України, 2016. С. 218-232.

8 Дутчак Г. О. "Відвідайте Україну, бо це є Європа" (хронограф українсько-австрійських культурних відносин) // Науковий вісник Дипломатичної академії України. К., 2002. Вип. 7: Зовнішня політика та дипломатія: теорія, історія, практика. С. 380-385.

9 Химинещь B. В. Українсько-австрійські відносини крізь призму санкцій країн СС проти Австрії // Науковий вісник Дипломатичної академії України. К., 2002. Вип. 7: Зовнішня політика та дипломатія: теорія, історія, практика. С. 243-248.

10 Меморандум про співробітництво між Міністерством культури і мистецтв України, Міністерством освіти України та Федеральним Міністерством освіти і культури Республіки Австрія. URL: http://zakon5.rada.gov.ua/laws/show/040_011 (дата звернення: 17.08.17). 
11 Угоди про науково-технічне співробітництво між Кабінетом Міністрів України та Урядом Республіки Австрія. URL: http://zakon5.rada.gov.ua/laws/show/040_020 (дата звернення: 17.08.17).

12 Меморандум про співробітництво між Міністерством культури i мистецтв України, Міністерством освіти і науки України та Федеральним Міністерством освіти, науки і культури Республіки Австрія. URL: http://zakon3.rada.gov.ua/laws/show/040_032 (дата звернення: 17.08.17).

${ }_{13}$ Культурно-гуманітарне співробітництво між Україною та Австрією. URL: http://austria.mfa. gov.ua/ua/ukraine-at/culture (дата звернення: 17.08.17).

${ }^{14}$ Сафар'янс $C$. Україна та Австрійська Республіка: співробітництво в європейському інтеграційному процесі // Український історичний збірник. Вип. 18. К.: Інститут історії України НАН, 2015. C. 267-276.

15 Меморандум про співробітництво між Міністерством культури і мистецтв України, Міністерством освіти і науки України та Федеральним Міністерством освіти, науки і культури Республіки Австрія. URL: http://zakon3.rada.gov.ua/laws/show/040_032 (дата звернення: 17.08.17)

${ }^{16}$ Оригінал: "die bis zum Ende der Habsburgermonarchie mit Galizien und der Bukowina besonders eng waren (...) nach dem Zusammenbruch der Sowjetunion auf vielfaltige Weise wiederbelebt”. Цит. 3: Slawinski, Ilona. Die Kulturbeziehungen zwischen Österreich und der Ukraine im 20. Jahrhundert /Viribusunitis. Österreich Wissenschaft und Kultur im Ausland. Impulse und Wechselwirkungen. Festschrift für Bernhard Stillfried aus Anlaß seines 70. Geburtstags, Bern/ Berlin/ Frankfurt am Main/ New York/ Paris/ Wien, 1996. S. 359.

${ }_{17}$ Agstner R. Von Kaisern, Konsuln und Kaufleuten - Österreich und die Ukraine 1785-2010. Münster, 2011. S. 200.

18 Österreichisch-Ukrainisches KooperationsbürofürWissenschaft, Bildungund Kultur. URL: http:// www.oesterreich-bibliotheken.at/verzeichnis2_oz.php?id=30 (дата звернення: 17.08.17).

19 Довідка про Національну академію наук України. URL: http://new.nas.gov.ua/UA/About/Pages/ default.aspx (дата звернення: 17.08.17).

${ }^{20}$ Demchenko $V$. Zustand und Perspektiven der ukrainisch-österreichischen Wissenschaftsbeziehungen // Der Donauraum. 1997. 4 (37). S. 42-47.

${ }^{21}$ Папенко Н., Лихачева О. Австрійсько-українські відносини: історичний вимір // Вісник Київського національного університету імені Тараса Шевченка. К.: «Київський університет», 2013. C. $51-55$.

${ }^{22}$ Можливість навчання в Австрії по програмі ЕРАЗМУС К1. URL: http://blogs.kpi.kharkov.ua/ oms/post/2016/04/29/Можливість-навчання-в-Австріi-по-програмі-ЕРАЗМУС-К1.aspх (дата звернення: 17.08.17).

23 Конкурс на отримання стипендій на навчання/стажування у Віденському університеті (Австрія) в рамках програми Erasmus+. URL: http://international.Inu.edu.ua/erasmus-university-of-vienna/ (дата звернення: 17.08.17).

${ }^{24}$ СТИПЕНДІЙНІ ПРОГРАМИ ОБМІНУ ЕРАЗМУС МУНДУС - ERASMUS MUNDUS. URL: http://interof.chnu.edu.ua/index.php?page=ua/10projects/erasmus (дата звернення: 17.08.17).

${ }^{25}$ Навчайся в Свропі. URL: http://eeas.europa.eu/archives/delegations/ukraine/documents/virtual library/study-in-europe uk.pdf(дата звернення: 17.08.17).

${ }^{26}$ Культурно-гуманітарне співробітництво між Україною та Австрією. URL: http://austria.mfa. gov.ua/ua/ukraine-at/culture(дата звернення: 17.08.17).

${ }^{27}$ Українська суботня школа в Відні: історія та розвиток. URL: http://www.ukr-schule.at/uk/school/ history (дата звернення: 17.08.17).

${ }^{28}$ Школа «Ерудит» у місті Відень. URL: http://austria.mfa.gov.ua/ua/ukraine-at/ukrainsry-navchalnizalady-v-avstriy (дата звернення: 17.08.17).

${ }_{29}$ Курси німецької мови. URL: http://mfa.gov.ua/mediafiles/sites/austria/files/Ogoloshennja_pro_ Kursy nimeckoi movy21.08.2015.pdf (дата звернення: 17.08.17).

${ }^{30}$ Центру німецької культури «Widerstrahl». URL: http://osvita.ua/languages/courses/8863/ (дата звернення: 17.08.17).

${ }^{31}$ Brait $A$. Wien-Moskau und Wien-Kiew. Der Zusammenbruch der UdSSR und die neue Unabhängigkeit der Ukraine aus der Wiener Perspektive // Австрія й Україна на історичних перехрестях: наук. 3б./ упоряд.: І. В. Жалоба, О. Р. Купчик, Л. В. Шпаковськи. К.: Дипломат. акад. України при МЗС України, 2016. С. 39-74.

${ }^{32}$ Міжнародна професійна науково-освітня програма УБА. URL: https://ula.org.ua/news/2016mizhnarodna-profesiyna-naukovo-osvitnya-programa-uba-metodologiya-ta-praktika-advokaciynoyi-diyal nosti(дата звернення: 17.08.17).

${ }^{33}$ Культурно-гуманітарне співробітництво між Україною та Австрією. URL: http://austria.mfa. gov.ua/ua/ukraine-at/culture(дата звернення: 17.08.17).

${ }^{34}$ Навчальна програма стажування у Австрії. URL: http://gurt.org.ua/news/grants/20544/bull/(дата звернення: 17.08.17).

35 У Патріаршому домі у Львові вручили дипломи медичним капеланам УГКЦ Австрійської освітньої програми для лікарняного. URL: http://news.ugcc.ua/news/u_patriarshomu_domi_u_lvovi_ 
vruchili_diplomi_medichnim_kapelanam_ugkts_avstriyskoi_osvitnoi_programi_dlya_likarnyanogo_dushpastirstva_79370.html (дата звернення: ${ }^{-}$17.08.17).

36 Папенко Н., Лихачева О. Австрійсько-українські відносини: історичний вимір // Вісник Київського національного університету імені Тараса Шевченка. К.: «Київський університет», 2013. C. 51-55.

37 Українська Суботня Школа у Відні. URL: http://austria.mfa.gov.ua/ua/ukraine-at/ukrainsrynavchalni-zalady-v-avstriy (дата звернення: 17.08.17).

${ }^{38}$ Папенко Н., Лихачева О. Австрійсько-українські відносини: історичний вимір // Вісник Київського національного університету імені Тараса Шевченка. К.: «Київський університет», 2013. C. $51-55$.

${ }^{39}$ В Університеті презентували антологію німецькомовних творів Івана Франка «Vivere Memento!». URL: http://www.Inu.edu.ua/v-universyteti-prezentuvaly-antolohiyu-nimetskomovnyh-tvoriv-ivanafranka-vivere-memento/ (дата звернення: 17.08.17).

${ }^{40}$ Культурно-гуманітарне співробітництво між Україною та Австрією. URL: http://austria.mfa. gov.ua/ua/ukraine-at/culture (дата звернення: 17.08.17).

${ }^{41}$ Виставка українського художника Дениса Савченка «Sehnsuchtsorte» у Лінці. URL: http:// storinka.at/events/vystavka-ukrayinskogo-hudozhnyka-denysa-savchenka-sehnsuchtsorte-u-lintsi/ (дата звернення: 17.08.17).

42 Концерт Академічного симфонічного концерту „Віденська осінь“ під керівництвом Курта Шміда. URL: http://www.loga.gov.ua/oda/press/news/koncert akademichnogo_simfonichnogo_koncertu videnska_osin_pid_kerivnictvom_kurta (дата звернення: 17.08.17).

${ }^{43}$ Культурно-гуманітарне співробітництво між Україною та Австрією. URL: http://austria.mfa. gov.ua/ua/ukraine-at/culture (дата звернення: 17.08.17).

${ }^{44}$ Українці у Відні «Dakh Daughters» фрік-кабаре. Австрія. URL: http://russianaustria.com/news/ dakh-daughters-band-freak-cabaret-austria-russian-vienna (дата звернення: 17.08.17).

${ }^{45}$ В австрійському Зальцбурзі 30 червня і 1 липня пройшли Дні української культури. URL: http://global-ukraine-news.org/ru/2016/07/08/v-avstrijskomu-zaltsburzi-30-chervnya-1-lypnya-projshlydni-ukrayinskoyi-kultury/ (дата звернення: 17.08.17).

${ }^{46}$ Культурно-гуманітарне співробітництво між Україною та Австрією. URL: http://austria.mfa. gov.ua/ua/ukraine-at/culture(дата звернення: 17.08.17).

${ }^{47}$ Австрійський журнал «Рodium» видав номер, присвячений українській літературі. URL: http:// www.nru.org.ua/allnews/item/377-avstriiskyi-zhurnal-podium-vydav-nomer-prysviachenyi-ukrainskiiliteraturi (дата звернення: 17.08.17).

${ }^{48}$ Культурно-гуманітарне співробітництво між Україною та Австрією. URL: http://austria.mfa. gov.ua/ua/ukraine-at/culture(дата звернення: 17.08.17). 